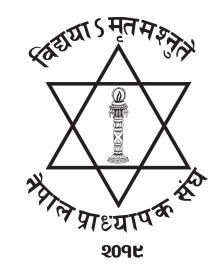

NJ: NUTA

\title{
Ibsen's The Pillars of Society: Female Protest against Patriarchy
}

\author{
Arjun Dev Bhatta \\ Department of English, Tri-Chandra Multiple Campus, Tribhuvan University, Nepal \\ Email: abhatta44@gmail.com
}

\begin{abstract}
This study explores social relationship between male and female in Henrik Ibsen's play "The Pillars of Society". The first part of the study analyzes a sexist society in which male characters subjugate females through their hegemonic power. The female characters appear meek, submissive and voiceless. The second part of this study examines the revolutionary role of the female characters who raise their voice against all-pervasive patriarchal power. They protest against male formulated institutions which have kept women voiceless and marginalized. Being dissatisfied with the defenders of patriarchal status quo, Ibsen's female protagonists come to the fore to challenge prevailing social conviction about femininity and domesticity. They lead a crusade to establish their position and identity as human beings equal to men. In this play, the female characters Lona, Martha and Dina hold a revolutionary banner to protest against male domination of female. In their constant struggle, they win while the male characters become loser. This study analyses the voice of these leading female characters in the light of feminist theory proposed by scholars such as Kete Millett and Sylvia Walby.
\end{abstract}

Key Words: domination, emancipation, oppression, patriarchy, protest

\section{Introduction}

Henrick Ibsen's The Pillars of Society (1877) is one of the first social plays that consistently dramatizes the familial and social issues based on gender inequality and differentiation. Gender conflict prevalent among nuclear or bourgeois families of his time can be taken as background of the drama. Ibsen's task was to expose social and familial imbalance in which men would appear more stronger than women. Being dissatisfied with this social structure and male prejudice against female, he attempted to speak in favor of the marginalized women through his dramatic art. Equally, his aim was to aware female individuals mainly for the purpose of liberty, right and equality. Therefore, he creates revolutionary women characters who protest against the conventional role of patriarchy to set up their own position. As a result, Ibsen's male characters turns out weak and displaced. Shideler writes; "A prominent theme within a number of Ibsen's social dramas is the weakening or displacement of the male protagonist, usually a husband and father whose awareness of his role as a "father figure" shapes his behavior" (1997 p. 278). His interpretation on Ibsen's social plays as; These plays are an expression of the struggle between the patriarch-oriented men and the biocentric-oriented women who argue in favor of 
a new social order through references to a knowledge base founded on human freedom and equality". He further states," Ibsen emerges as one of the most important advocates for the improved status of women in the second half of 1800s (Lorentzen 2006 p. 818).

No doubt, the 'father figure' in this play seems weak and displaced. Karsten Bernick, a consul, and the town's leading citizen is an epitome of weak and displaced father.

The Pillars of Society dramatizes a story of local patriarch Consul Bernick who leads a life of lie and deceit. Lona Hessel and Johan Tonnesen return from America to expose to the public Bernick's deceit upon which his marriage and business has been built. Much of the play focuses on Bernick's patriarchal status in the coastal town. As a pillar of the town, he assumes himself godlike role over the town's people. The town itself relies on him and his guidance. The town's men seem ignorant regarding his hidden plan on becoming financially strong when the railroad comes to the town. But Bernick's strong familial and social foundation is shaken with Lona's intrusion into his society. Lona openly discloses hidden mystery of Bernick's nature as hypocrite, liar and dishonest father at a ceremony in honor of Bernick when Rorlund, the hypocritical spokesman eulogizes Bernick's virtue. At this juncture, Bernick acknowledges his past mistakes, and recognizes that his lust for name and power poisoned and blinded him. When his eyes are opened, he publicly proclaims that 'women are the pillars of society', and for the first time in his life, he invites his wife, Betty and his sister, Martha to his practical life they have long been excluded.

The objective of this article is to expose an unequal relationship between male and female. This study is concerned with how male protagonists treat and manipulate female individuals to sustain their power, and how the female characters resist patriarchy and win their position in the male stringent society. In so doing, the study focuses on female roles, their voices, words and language. I have analyzed the role of both class of beings from feminist perspective. There are number of feminist activists who have different views on patriarchy and its oppression of women. However, my study is concerned with the feminist views on patriarchy developed by Kate Millet, Veronica Beechey and Sylvia Walby. Kete Millett argues that patriarchy is an exposition of power which takes the form of male domination over female in all sphere of life. Sylvia Wlaby, on the other hand, stresses patriarchy as a social system in which men dominate, oppress and dehumanize women.

This study displays long remaining gap between two sexes. It encourages women to raise voice for their coexistence with men. Similarly, it hopes to generate in men the sense of egalitarianism, and behave and respect women as equal social counterpart in their everyday life. In addition to it, the study promotes women to see their identity, resist domination over them and participate in various activities to maintain their access in all mainstream spheres of life.

\section{Patriarchy and Its Domination: A Theoretical Aspect}

Patriarchy refers to macho ideology predominantly exposing man's overall dominance in all aspects of human activities to subjugate women. It always creates psyche to marginalize women socially, politically, psychologically and culturally. Broadly speaking, patriarchy connotes undermining and dehumanizing women in all scenario of life in contrast to man's glorified roles. Patriarchy assumes man as 'self', god's representative and power whereas woman as 'other', man's inferior part and powerless. In a patriarchal society and culture, a woman is punished by restrictions, dependence, overburden of inward duties and subordination. Man exerts his power over woman, and as such subordinates and 
controls her interests, wishes and desires through coercion or physical violence. Leslie Heywood defines the concept patriarchy as "a general system, where social practices, institutions (Church, family, state), and cultural images organize the power that men exert over women" (2005 p. 239). In a patriarchal system, men hold primary power and possess social privilege, political leadership, moral authority and control of property; Maggie Humm also states as; "a system of male authority which oppresses women through its social, political and economic institutions .... Patriarchy has power from men's greater access to, and mediation of, the resources and rewards of authority structures inside and outside the home (2003 p.200). It is a system in which men perform hegemonic force over women. It dominates women as sexually 'others' and are marginalized and suppressed. It "appropriates power for men and, exercising this power, limits women's social roles.” (Walkington, 1991 p.65). Similarly, Peter Barry sees it a "cultural 'mind-set' in men and women which perpetuated sexual inequality." (2013 p.117)

Although feminist activists have different views on this concept across time and space, they observe that patriarchy as a systematic bias against women and insist that oppression of women is the product of this underlying bias of a patriarchal society. Valerie Bryson says that "a social system based on male domination and female subordination has become standard amongst feminists (2003 p.166). She further states; “the task of understanding patriarchy involved the identification of women's oppression across cultures and nations and over time" (2003 p.170). In fact, patriarchy reinforces male power over women, and subjugates them so as to let them believe in male superiority. So, patriarchy "provides a system of control and law and order." (Eistenstein qtd in Walby, 1889 p.215). By suppressing their emotions, intellect and capability, it keeps women in a narrow cage where they are intimidated and forced to speak the same male language, which they have long been taught. In such a society, "women frequently appear as object of men's desires or fears, but never complex autonomous individuals." (Tolan, 2007 p.321). For various women's movements, the term 'patriarchy' has become a serious subject of discussion. However, the women's movements have used the concept of patriarchy to analyze the principles underlying women's oppression. In this regard, Verona Beechy writes: "the theory of patriarchy attempts to penetrate beneath the particular experiences and manifestations of women's oppression and to formulate some coherent theory of the basis of subordination which underlies them." (1979 p.66). Silvia Walby defines patriarchy as "a system of social structure and practices in which men dominate, oppress and exploit women.” (1989 p.214). She claims that patriarchy is not a universalistic notion rather can take different forms. For her, there are two major forms of patriarchy - private and public. Private patriarchy is visible at home where the father figure controls all the family members male or female. Here, women are excluded from arenas of social life apart from household activities "with a patriarch appropriating women's services individually and directly in the apparently private sphere of the home. Public patriarchy does not exclude women from certain cites, but rather subordinates women in all over them. In this form of appropriation of women takes place more collectively than individually" (Walby 1989 p.228). Thus, we can say that patriarchy initiates from childhood socialization within the family and spreads its roots to cover all spheres of life, and manifests itself in the institutional arenas such as social, political, legal, religion and policy making.

The American radical feminist Kate Millet observes absolute rule of a father over his family as sanctioned by God and nature. She takes such familial power as her starting-point, so that "the principles of patriarchy appear to be twofold: male shall dominate female, elder male shall dominate young." In her book Sexual Politics (1985), she shows sexual relationship based on power as; 
In all known societies relationships between the sexes have been based on power, and that they are therefore political. This power takes the form of male domination over women in all areas of life. Sexual domination is so universal, so ubiquitous and so complete that it appears 'natural' and hence becomes invisible, so that it is perhaps the most pervasive ideology of our culture and provides its most fundamental concept of power. (qtd. in Bryson, 166)

This shows that patriarchal power of men over women is pervasive in all societies and extends far beyond formal institutions of power. In a hegemonic power of men, women may show inward outlets such as self-hatred, self-rejection and inferiority what Millet calls 'interior colonization'.

The above-mentioned feminist activists and their views on patriarchy provide us with sufficient tasks to analyze Henrik Ibsen's drama The Pillars of Society. The play is about the female characters who abandon traditionally assigned role of women in a patriarchal society, and question the hegemonic role of long-standing patriarchy. These assertive female characters strategically counter male power and establish their own position in the typical patriarchal society. The leading female characters in the play are not passive followers and supporters of the biased tradition rather they are more revolutionary fighting for their freedom, equality and identity. They do not remain prototype of conventional submissive daughters, wives and sisters, but conceive themselves entire human beings responsible for their rights irrespective of their gender.

\section{Male Domination and Female Subordination}

At the beginning of the play, Ibsen presents prototype of traditional women who have internalized patriarchal norms and values. Betty Bernick, Mrs. Rummel, Mrs. Holt and Mrs. Lynge are example of "good girl" (Tyson 2006 p. 89) because they acquiesce to patriarchy and obey its rules and regulations. They lack courage to raise voice against their oppression by the male protagonists such as Consul Bernick, Rorlund, the school teacher and the Shipwright Aune. Bernick holds power over all the coastal citizens male or female. Rorlund in the name of morality dominates and manipulates these women whose life is confined to needle work in a large garden room in Bernick's house. He applies patriarchal strategy to keep them in their status quo, and speaks in disguise that they are "sacrificing in a good cause", and persuades them as: "the First Aid Detachment, a Red Cross unit that prepares the lint for these unhappy victims, lays the bandages gently upon their wounds, cures and heals them". (Act I, p.28). The wide disparity between male and female is exposed by Rorlund when he reads aloud to the group of ladies from a gilt-edged book entitled 'Woman as the Servant of the Community'. By the same coin, Bernick with two other capitalists Rummel and Vigeland exploit women keeping them in a dark room, and force them to serve and praise their husbands. These women are kept silent, and are excluded from public spheres. They only pursue maternal role and face social and economic restriction. Ibsen observed this mirror-image of nineteenth century social relationship and first attempted to portray it in this drama. Sylvias Walby in Theorising Patriarchy represents real picture of women's plight in the male dominated society as; Middle class women were excluded from the public sphere. Women, especially married women and middle-class women, rarely worked in public, only in their households. There were strong sanctions against non-marital sexuality for such women. Women were excluded from the public sphere of the state, lacking citizenship rights such as suffrage and, if married, the ability to own property, Husbands' violence against wives was condoned. Cultural institutions, such as the Church, supported the nation that woman's place was in the home. (1989 p.228) 
Bernick has suppressed his wife's feelings, intelligence and opinions. He discourages her vested interest in business transection, and says that she is not fit in such a field: "Women wouldn't have been able to grasp the real nature of business." (Act I, p.44) In this regard, Virginia Woolf writes in Room of One's Own: "Our mothers were not given the chance to learn the art of making money, and it in this economic poverty that has underlain the intellectual impoverishment of women". (2001 p.13)

Bernick forwards patriarchy's popular view on women whose sole duty was to be helpmate and comfort their husbands. He tells the group of ladies working under him: Bernick: We, the practical men of affairs, support society by spreading prosperity in as wide a circle as possible. And our womenyes, come in ladies; you are welcome to hear this- our women, I say, our wives and daughter- you must go on working undisturbed, ladies, at your benevolent tasks, and be at the same time, a help and comfort to those nearest you, as my dear Betty and Marta are for me and Olaf. (Act I, p.44)

Bernick and Rorlund, the representation of nineteenth century fathers, keep the women back of curtain who have been taught to accommodate their nature to their husbands' way of thinking. This kind of built-in slavery and exploitation of women the leading feminist Betty Friedan calls 'The feminine mystique'.

Bernick's patriarchal foundation was contaminated with different types of sins. He once misused his physical strength seducing a circus star, Mrs. Dorf, mother of Dina Dorf and made Johan Tonnesen a scapegoat of this crime. He purchased her with money to hide his sin. Equally, he trampled Lona's love and sentiment having married with Betty for his financial and social standing. In spite of his sins, he thrives and becomes stronger and free when Tonnesen goes to America with Lona shouldering Bernick's crime and accusation. In this way, the corrupt Bernick has earned and made his strong social standing as a pillar of society.

\section{Bernick and Lona: Patriarchy versus female protest}

Ibsen simultaneously presents the role-play of strong and bold female characters who renounce traditional conception of femininity and gender ideology. Lona Hessel, Miss Martha and Dina Dorf are female combatants who openly challenge the biased social system ingrained in male power. Susan Torrey Barstow writes: "Ibsen's heroines did not face starvation, shipwreck, or attack by wild animals instead they struggle the thralls of domesticity and confines of traditional femininity. (2001 p.389). These female protagonists question not only the male ambition of female as dutiful daughters and submissive wives but also "set a new trend by challenging male authority and attempting to remake the world created by men” (Banerjee 2006 p.1). The spirited woman Lona Hessel grows strong in a wide American society by entering into a public field singing in cafes, giving public lectures and writing controversial books. She has sacrificed her life for the betterment of Johan Tonnyson, from whom she identified hidden story of her one-time lover, Bernick. She has broken patriarchal ideology that defines 'feminine' clothing and get-up by getting her hair short and wearing male dress. She does not appear patriarchal production of the helpless woman stereotype.

The conflict begins when Lona enters Bernick's narrow society with a revolutionary crusade after fifteen years' self-exile. Her home-coming is a multifarious objective. First, she has to "help Bernick get solid ground under his feet" (Act II, p.81), and, by so doing, she has to correct his sham, hypocrisy and false idealism. By the same coin, she has to make Bernick renounce his dominating feeling of patriarchal egoism. Her another object was to emancipate Dina Dorf from Bernick's 
suffocated patriarchal society and send her to America to make her free and independent. Similarly, she has to educate the group of women who have long been in the isolation of Bernick's society suffering the pressure of Puritanism. Thus, the play reflects two main situations: breakdown of male authority represented by socially acclaimed pillar, Bernick, and renunciation of patriarchy by women who announce themselves free of patriarchal heritage that only saw women merely as wives and mother or spinster. In Lona's presence, the patriarchal morality and idealism comes to an end.

As soon as Lona enters the stage, she attacks the dark atmosphere of Bernick's room and the women working with clothes. The white clothes she takes as smell of mortality and shrouds, since she is "used to the air of the prairies" (Act I, p.50). The male hegemony is threatened forthwith when Lona reveals her mission to those patriarchs Bernick and Rorlund. In response to Rorlund's question about what she can do for society, she symbolically replies: "I am going to let some fresh air" (Act I, p.51). Lona's symbolic announcement Ross Shideler observes as: "In essence to let in some fresh air she has brought from American prairies indicates her mission to overcome the corrupt Norwegian patriarchal family and replace it with a new more democratic family" (1997 p. 251). Her courage and boldness are realized when she slapped Bernick's ear before she went to America. Her slapping can be taken as female power and challenge to patriarchal ideology. Lona is corrective to Bernick's rotten patriarchy that is based on treachery and life-long lie which she wants to cure. In her conversation with Bernick, Lona affirms that his family and authority is badly contaminated by his life-lie, and his good reputation and name is in grave peril. Even his son, Olaf disobeys him and plans to run away. In this critical situation Bernick surrenders to Lona as: Bernick: Because I have been thinking a good deal lately- since you came back- and especially this evening. Ah, Lona, why didn't I know you, your real self, then- in the old days (Act IV, p.120).

Bernick is defeated; his machismo is completely destroyed. He atones for the crime, and publicly announces that all he had done in the name of society was his own personal gratification, not societal development and its solidarity. He considers himself feckless, and not worth the title "pillar of society'. Instead, he proclaims "It was women who are pillars of society" (Act IV, p.137). Sylvia Walby claims that patriarchy is not monolithic structure of the society. Women may challenge it and bring changes through their continuous struggle. Lona brings complete change in Bernick; he is reformed. He overthrows his hegemonic role of father and husband and allows women to enter male world as: Bernick: Not for anything in the world. Where have I been? You will be shocked when you know. Now I feel as if I had come to my senses after being poisoned. But what do I feel that I can be young and strong man. Oh, come nearer, closer around me. Come, Betty, come, Olaf, my boy! And you Marta - I don't seem to have seen you all these years. (act IV, p.136)

Lona's feminist mission is accomplished when Bernick confesses his crime and sincerely acknowledges Lona's mission: "Thank you, Lona, you saved the best in me - and for me" (Act IV, p.135). The goal of Lona's mission was not self-centered. It was to create a beautiful and ideal society where human relationship would not be based on domination and discrimination. Lona's egalitarian mission is complete at the end of the play breaking Bernick's patriarchal authority.

\section{Miss Marta and Dina as female rebels}

These two female characters in the play exhibit Lona's spirit as well. Both of them constantly struggle against Rorlund's false ideal and Bernick's supremacist conception as pillars of society. Like 
Lona, they can be seen as rebel force against male prolific social system, and raise the banner of emancipation. Like Lona, Marta, fights for Dina's emancipation and advises her to break the forced engagement with so-called idealist Rorlund and elope promptly to America, a country she herself imagines, "must be beautiful there; the skies are wider; the clouds move higher than here; freer wind blow over head" (Act IV, pp.116-17). She fortifies Dina's dormant spirit in this dialogue: Miss Bernick: No, I can well believe it; I didn't expect it of myself. But it was bound to come to the breaking point sometime. Oh, what we supper here under the tyranny of custom and conviction? Rebel against it, Dina. Be his wife. Let there be something to defy all this tradition and habit. (Act IV, p.116).

Although Marta is not as open as Lona, she is a woman of mission which is centered on Dina's long imprisonment in her own brother's house. The revolutionary spirit of these two women and Ibsen's delineation of active female role Clement Scott describes in The Daily Telegraph as follows: The more dramatist talks the more we like him. He is a companion and friend. We are attached to Lona, and admire her spirit and self-sacrifice. We can feel every beat of Bernick's heart, understand his temptation and appreciate his mental agony. We picture Marta as one of the loveliest characters in dramatic fiction. We picture the scene; we have lived in the 'community' every human being on the canvas is similar to us. (Qtd. in Egil 1995 p.128)

Dina's role is also worth mentioning. She is a budding 'New Woman' having a dream of independence. She is fed up with unjust, commercialized and denatured society led by Bernick and Rorlund, and wants to enter into an open and wide society where "neither the men nor the women are respectable and moral, but natural". She "has horror of respectability" (Act IV, p.115). Dina assumes Rorlund's love for her in a moral pretense. She wants to eschew the false male society which under the mask of love and morality oppress women. As an individual, her first priority is to spend a carefree life. For her, love and marriage are sharpest weapons that destroy woman's freedom and enthusiasm. Her voice echoes Simone de Beauvoir who evaluates marriage as "oppressive and exploitative economic management, which reinforces sexual inequality and binds women to domesticity" (qtd, in Tolan p.321). Rejecting traditional role of a married woman, Dina prioritizes work to become independent and free what Lona calls 'the spirit'. In Beauvoir's fashion, she dominates the belief that true happiness is not marriage, but liberty and freedom that helps maintain human existence peacefully and comfortably. In marriage, a woman is excluded from pursuit of knowledge where she leads an animal life merely producing children, and has limited and defined liberty. Valerie Bryson forwards early radical feminist view on love and marriage that "marriage perpetuates a form of domination disguised by love. Love in a patriarchal society cannot be based upon equality, but reflects women's economic and social dependency and ensures that they will not challenge their subordinate position" (2003 p.178). The radical feminist Shulamith Firestone also argued that "Love, perhaps even more than child bearing, is the pivot of women's oppression today" (1979 p.121). Similarly, Kandiyoti writes that "women have very little to gain and a lot to lose by becoming totally dependent on husband, and hence they quite rightly resist project that tilt the dedicate balance they survive to maintain" (1988 p.277). Dina is already familiar with these institutions that is why she rejects marriage with Tonnyson. She expresses her desire and purpose in America is "to work first and become something myself, just as you are. I won't be just a thing that is taken (Act IV, p.116). Pursuing her intellectual and emotional potential, she will exhibit herself a self-reliant individual capable of sustaining her happy life. She will think, work and act like a man, and instead of bemoaning her inferiority to man, she will declare herself equal. 


\section{Conclusion}

The female characters in this play openly challenge the profoundly established stringencies of male dominated society. It is not their blind acceptance of male treatment of female rather to set up their position and ground as independent human beings. The real merit of this play is the theme of women's right. Ibsen's delineation of assertive female role is his demand for individual's freedom, equality and recognition in a society. He found women lacking these basic needs that is why he dares to speak for women. The present play is an exploration of women's life in male oppressive society which is built on a foundation of sham and lies. It is entirely male world that marginalizes female as 'other'. In this biased world, women can neither lead a happy and prosperous life nor can develop their personality freely. But Ibsen's play presents male heroes displaced and their Christian patriarchal world turned upside down. This play exposes a conflict between idealized notions of the patriarchal family and women's struggle for their position. The women characters in 'The Pillar of Society' struggle to deconstruct patriarchy to create a society which will see and judge female as equal social members.

\section{References}

Banerjee, S. K. (2006). Feminism in Modern Drama. Atlantic.

Barstow, S. T. (2001). 'Hedda is all of Us: Late-Victorian Women at the Matinee. Victorian Studies, 43(3), (387-411).

Beechey, V. (1979). On Patriarchy. Feminist Review, 3(1), 66-82.

Bryson, V. (2003). Feminist Political Review. Palgrave MacMillan.

Heywood, L. (2005). The Women's Movement Today. Rawat Publications.

Humm, M. (2003). The Dictionary of Feminist Theory. Edinburgh University Press.

Ibsen, H. (1961). The Pillars of Society. In Una Ellis-Fermor (trans.), Hedda Gabler and Other Plays (pp 23-137). Penguin Books.

Kandiyoti, D. (1988). Bargaining with Patriarchy. Feminist Review, 2 (3), 274-290.

Lorentzen, J. (2006). Ibsen and Fatherhood. New Literary History, 37(4), 817-836.

McHugh, N. A. (2007). Feminist Philosophies A-Z. Edinburgh University Press.

Shideler, R. (1997). Ibsen and the Name - of - the - Father. Scandinavian Studies, 69 (3), 277-295.

--- ---- ---- (1997). Darwin, Weak Men, Strong Women and Ibsen's Pillars of Society. Comparative Literature Studies, 34, 242-259.

Tolan, F. (2006). Feminism. In Patricia Waugh (ed.), Literary Theory and Criticism (pp 319-339). Oxford University Press.

Tornqvist, E. (1995). Ibsen: A Doll's House. Cambridge University Press.

Tyson, L. (2006). Critical Theory Today. Rutledge

Walby, S. (1989). Theorising Patriarchy. Sociology, 23(2), 213-234.

Walkington, J.W. (1991). Women and Power in Henrik Ibsen and Adrienne Rich'. The English Journal, 80(3), 64-68.

Woolf, V. (2001). A Room of One’s Own. Foundation Books. 